\title{
初乳中ビスフェノール $\mathrm{A}$ 濃度と 食器包装容器使用との関連
}

\section{Maternal exposure to BPA leaching from beverage and food containers and its lactational transfer}

\author{
立岡弓 子 (Yumiko TATEOKA)*
}

目的

抄録

プラスティック食器容器の原材料であるポリカーボネイト樹脂・ポリスチレン樹脂から, 内分泌擋乱 物質の一つである，ビスフェノールA（以下，BPA と記す）が溶出することが問題になっている。BPA は, 日常生活においてごく微量ながら食生活を通して体内に取り込まれている可能性が高いが，母乳污 染に関する研究は行われていないため, 授乳する母親の食生活でのBPA の摂取状況との関連を明らかに する。

方 法

出産後 3 日目の授乳婦102名を対象に, 初乳検体を採取した。食器包装容器の質問紙調査では, ポリ カーボネイト製耐熱容器・ペットボトル飲料水・コンビニ弁当・カップめん・缶コーヒー飲料について, 使用状況を調査した。抗 BPA 抗体を用い，96穴マイクロプレート上にて ELISA 法により，研究者自身 が102検体の初乳中 BPA 濃度を測定した。

\section{結 果}

初乳102検体 (100\%) から BPA が抽出された。初乳中 BPA 值は3.41 $\pm 0.13(\mathrm{~m} \pm \mathrm{SD} \mathrm{N}=102)$ $\mathrm{ng} / \mathrm{ml}$ であった。そして, BPA が溶出する食器包装容器を使用した頻度の多い授乳婦から分泌された初 乳中 BPA 濃度が，高い傾向を示した。

\section{結 論}

内分泌摫乱物質である BPA は，すべての初乳検体から検出された。普段の食生活において，BPAの 摂取経路を絶つことが母乳哺育を行ううえで大切なことであると考えられた。

キーワード 内分泌擋乱化学物質, ビスフェノールA, 初乳

\section{Abstract}

\section{Purpose}

The aim of this study was to clarify the relationship between the intake of BPA leaching

*静岡県立大学看護学部 (School of Nursing, University of Shizuoka) 
out from plastic food and beverage containers by pregnant women and lactational transfer of this industrial compound.

\section{Method}

Initial breast milk samples obtained 3 days after birth were collected from 102 lactating women. In addition, a questionnaire survey was conducted to determine the extent of use of plastic food containers and packaging material, such as heat-resistant polycarbonate food containers, as well as the consumption of plastic-bottled water, takeout meals packaged in polycarbonate plastic and canned coffee, by these women when they were pregnant. The BPA level in the first breast milk samples was quantified by ELISA using anti-BPA antibody.

\section{Results}

Initial breast milk samples could be obtained from all of the 102 subjects. The BPA level in these samples was $3.41 \pm 0.13$ (mean $\pm \mathrm{SE}$ ) $\mathrm{ng} / \mathrm{mL}$. The BPA levels in the breast milk tended to increase as the frequency of use of plastic food containers and packages made with BPA by the subjects when they were pregnant increased.

\section{Conclusion}

For safe breastfeeding, we believe that it is important to minimize maternal exposure to BPA throughout life, not only during pregnancy.

Key Words Endocrine disruptor, Bisphenol A, Initial breast milk

\section{I 緒 $\overrightarrow{\text { 言 }}$}

1996年ごろより，ごみ焼却によるダイオキシン 類の問題が取りざたされ，母乳栄養の選択にマス コミの影響が出始めており，授乳する母親の不安 を募らせている。基礎医学系の研究者らは，かな り高濃度のダイオキシン類をラットに暴露させ, 胎児における生殖系への影響を報告しているが, 本来の暴露濃度での検討は行われていない。ダイ オキシン類等環境ホルモンと母乳栄養の問題に関
しては，助産師が中心となり臨床に即した研究を 行うことは急務と思われる。

ダイオキシン類を含めた内分泌擋乱化学物質に 関する厚生労働省・環境庁・WHO の見解は, 表 1 に示すとおりである。

最近，ペットボトルの普及により，私たちの日 常生活の中で，極微量ながら食生活を通して体内 に摂取されている内分泌擋乱化学物質の中に， ビスフェノールA（以下BPA；2,2-bis (4hydroxyphenyl) propane) という物質がある。 BPA は，プラスティック容器の原材料であるポリ

\section{表 1 内分泌撕乱物質に関する見解}

\section{WHO 1987年ワーキンググループ勧告より}

母乳には，内分泌筧乱化学物質が含まれているが，母乳栄養には乳幼児の健康と発育に関する利点を示す明確 な根拠があることから，母乳栄養を奖励し推進するへきざある。

平成12年厚生白書「ダイオキシン類濃度等に関する調查研究」報告書より

母乳の損取期間は短く，栄盖や免疫の有効性を考慮すれば，安易に母乳を止めるべきではない。

環境庁（現・環境省）1997年ダイオキシンリスク評価検討会報告より

現時点で，母乳中の内分泌摫乱化学物質が乳児に与える影響は，直ちに問題にあるとは考えられず，引き続き 母乳栄養とすることが適当とされる。また，今後とも継続して母乳の安全性を確保していくため，その発生源対 策や研究について行うへきである。 


\section{表 2 BPAを溶出する可能性のある食器包装容器}

ポリカーボネイト製耐熱容器

プラスティック製容器

ペットボトル飲料

コンビニ弁当

カップめん

缶コーヒー

カーボネイト樹脂・ポリスチレン樹脂・ポリ塩化 ビニル樹脂から溶出する。日常の食生活において BPA を捸取する可能性のある食器包装容器を表 2 に示した。どれも，私たちの日常にある容器であ る。先行研究では, 妊婦の血清中・臍帯血中 BPA 濃度が測定され, 胎児への移行が懸念されて いる（Takeuchi ら，2002)。これまでに，母乳中 BPA 含有量を測定した研究報告はない。

今回, 授乳場面に多く関する助産師として, 授 乳する母親の BPA 摂取状況と母乳栄養に関する意 識を調查し, 初乳中 BPA 含有量について明らかに したので報告する。

\section{II 目 的}

食生活を通して体内に蓄積された BPA が，初乳 からどの程度排泄されているのかを，妊娠中の食 生活のなかで使用した食器包装容器の利用状況と の関連から明らかにする。

\section{III 方法}

\section{1. 対 象}

平成13年 6 月から11月に $\mathrm{S}$ 総合病院で出産した 初産・経産婦102名。

\section{2. 調查方法}

\section{1）授乳する母親の背景}

年齢, 妊娠分婏歷, 母乳栄養の意識, 出生時体 重, BPA の認知。

\section{2 ) 初乳検体の採取}

分婏後 3 日目に, ガラスの哺乳瓶に用手搾乳し $-30^{\circ} \mathrm{C}$ で冷凍保存した, ガラスの哺乳瓶の蓋は, プラスティック製のため使用せず，アルミ箔で覆つ た。

\section{3 ) 食器包装容器の使用状況の調査}

プラスティック容器を原材料とした食器包装容 器は, 配膳から摂取までの短時間に食べ物に接す ることや，加熱処理をした食べ物が触れることで BPA を溶出する。缶コーヒ一飲料を摄取した 1 時 間後で，1 本の缶コーヒー飲料から溶出される $\mathrm{BPA}$ 溶出量の約 $16 \% ， 2$ 時間後には約 $18 \%$ の BPA が尿中に排泄されることから，体内に摄取さ れた BPA は，腸管で吸収後に尿中に排泄されるこ とが報告されている（小平ら，2000）。分婏後72時 間以内に分泌される母乳成分は, 妊娠末期から分 婏時の身体血液成分を反映している（William, 1989年) ことから, 表 2 に示した食器包装容器の 項目の妊娠末期の食生活・分婏入院当日までの使 用状況を調查した。使用頻度については， 1 週間 単位の摄取状況について「まったく使用しない・ 摂取しない」・「使用・捸取した」に分類した。

\section{3. 初乳の前処理と BPA 濃度の測定}

初乳の前処理は, 立岡 (2003) と久留戸ら （2003）が報告した方法に準じて行った。BPAの 測定は，（エコ・アッセイ BPA ELISA Kit；大塚 製薬）を使用して研究者自身が実施した。BPAの 添加回収試験を実施し, 添加回収率の一致率を検 討した。また同一検体にて, 高速液体化クロマト グラフィーと ELISA 法との濃度の一致率を検討し た。その結果をもとに，測定の信頼性・妥当性に 関しては，大塚製薬アッセイ研究所の臼杵先生に ご指導をいただいた。

\section{4. 倫理的配慮}

この研究は, 研究のデー夕収集に先立ち, 静岡 県立大学看護学部倫理委員会の審査・承認を得た。 研究対象者には, 研究デー夕は研究目的以外に使 用しないこと，すべて匿名で処理し個人が特定で きないようにすることを保証した。

なお, 研究対象者の要望により, BPA 濃度結果 は，郵送にて通知した。

\section{5. 分析方法}

分析は統計ソフト SPSS Ver.11を用いて，基礎 統計, 対応のない $\mathrm{t}$ 検定を行った。有意水準は $5 \%$ とした。 


\section{IV 結 果}

\section{1. 対象の背景}

102名の母親のうち, 初産婦は49名, 1 経産婦 34 名, 2 経産婦15名, 3 経産婦 4 名であった。出産 時の平均年齢は, $30.5 \pm 4.6(\mathrm{~m} \pm \mathrm{SD})$ 歳, 初乳 採取日の 1 日総母乳分泌量は, $205.9 \pm 168 \mathrm{ml}$ あった。出生時体重は $3,004 \pm 429 \mathrm{~g}$ であった。

102名の母親のうち，BPA について知っていた 母親は 30 名 (29\%) であり，授乳することへの不 安を抱いていた母親は14名（13.7\%）であった。 不安は抱いていたが，直接授乳をすべての母親が 実施していた。

\section{2. 初乳中 BPA 濃度}

分婏後 3 日目に採取した初乳中 BPA 濃度は, $3.41 \pm 0.13(\mathrm{~m} \pm \mathrm{SD}) \mathrm{ng} / \mathrm{ml}$ で，最小值は1.41 ng/ $\mathrm{ml}$ で最大值は7.13ng/ml であった。そして初乳 102検体（100\%）すべてから BPA が抽出された。

\section{3. 分娩歴による初乳中 BPA 漕度（図 1 参照）}

初産婦（49名）の初乳中 BPA 濃度は3.13ng/ $\mathrm{ml}$, 経産婦 (53名) は3.63ng/ml であり, 対応の ない $\mathrm{t}$ 検定にて統計学的有意差は認めなかった $(\mathrm{P}=0.074)$ が，経産婦で高い傾向を認めた。

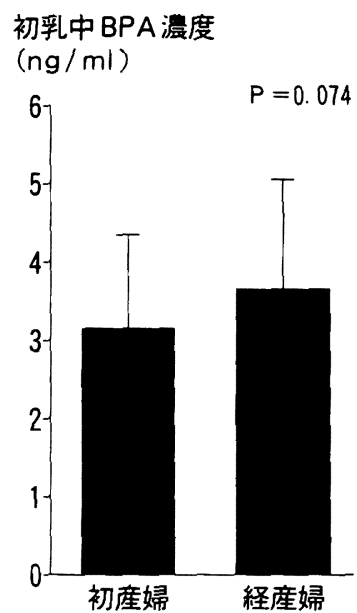

図 1

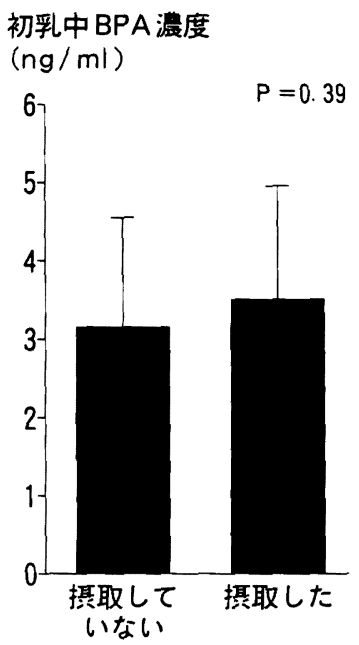

図2
分婏歴による 初乳中BPA濃度

4. 初乳中BPA 漕度と食器包装容器使用との関連 1) ポリカーボネイト製耐熱容器（電子レンジと の併用使用）

作り置きしておいた食品をポリカーボネイト製 耐熱容器に入れ，電子レンジで温めて使用してい た母親は 32 名で初乳中 BPA 濃度は $3.11 \mathrm{ng} / \mathrm{ml}$, まったく使用しなかった母親は70名で $3.21 \mathrm{ng} / \mathrm{ml}$ で あった（P=0.32）。

\section{2 ) ペットボトル飲料}

ペットボトル飲料水を摃取した母親は，78名と 多く，飲まずに煮出したお茶を飲むようにしてい た母親は24名であった（図 2 ）。自宅で煮出したお 茶や麦茶をペットボトルに入れていたものは, 飲 んでいた群とした。飲んでいた群は初乳中 BPA 濃 度が $3.48 \mathrm{ng} / \mathrm{ml}$ で, 飲まなかった群は $3.14 \mathrm{ng} / \mathrm{ml}$ であり, 統計学的有意差は認めなかった（ $\mathrm{P}=$ 0.39）が，飲んでいた群で濃度が高い傾向を認め た。

\section{3 ) コンビニ弁当}

電子レンジで 1 分以上温め, コンビニ弁当を食 べた母親は64名で, 初乳中 BPA 濃度は3.32ng/ $\mathrm{ml}$ ，まったく食べなかった母親は，38名で3.26ng/ $\mathrm{ml}$ であり, 統計学的有意差は認めなかった（P= 0.78 )。

\section{4 ) カップめん}

発泡ポリスチレン樹脂勢カップ麵容器で, 熱湯

初乳中BPA 濃度 ( $\mathrm{ng} / \mathrm{ml}$ )

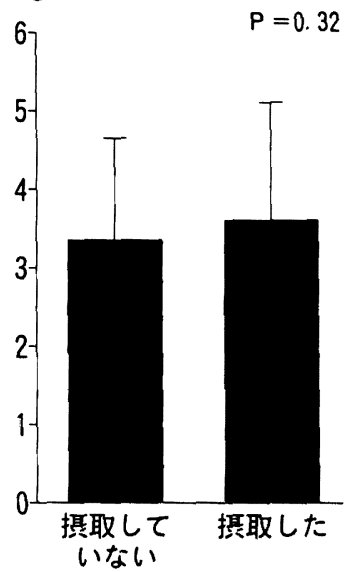

図3

カップめんの摂取と 初乳中BPA濃度
初乳中BPA濃度 $(\mathrm{ng} / \mathrm{ml})$

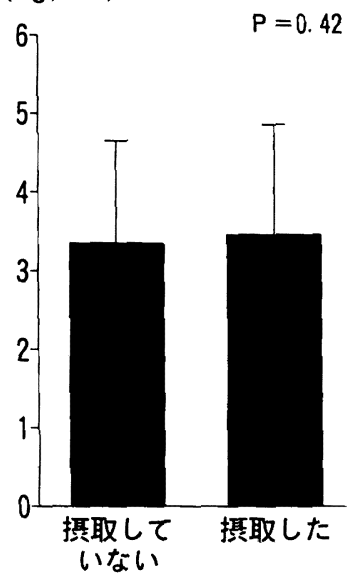

図 4

缶入り飲料の撕取之 初乳中 BPA 浱度 
を入れてカップめんを食べた母親は30名で，初乳 中 BPA 濃度は3.62 $\mathrm{ng} / \mathrm{ml}$, 食べなかった母親は72 名で $3.34 \mathrm{ng} / \mathrm{ml}$ であった（図 3 )。統計学的有意 差は認めなかった（P=0.32）が, 妊娠中にカッ プめんを食べていた群で, 初乳中 BPA 濃度が高い 傾向を認めた。

\section{5 ) 缶コーヒ一飲料}

缶入り茶でなく, 缶の内側にエポキシ樹脂がコー ティングされているコーヒー飲料を調査対象とし た。飲んだ母親は56名で, 初乳中 BPA 濃度は $3.43 \mathrm{ng} / \mathrm{ml}$ ，飲まなかった母親は46名て $3.36 \mathrm{ng} / \mathrm{ml}$ であり, 統計学的有意差は認めなかった $(\mathrm{P}=$ 0.42）が, 飲んでいた群で初乳中 BPA 濃度が高い 傾向を認めた（図 4 )。

\section{5. 初乳中BPA 濃度と食器包装容器複数使用との}

\section{関連}

使用した群で初乳中 BPA 濃度が高い傾向を認め た，カップめん・缶コーヒー飲料・ペットボトル の複数使用頻度による濃度差を, 図 5 に示す。 カップめん・缶入りコーヒー・ペットボトルの 3 種類をまったく攝取しなかった母親は 46 名， 1 〜 2 種類摂取した母親は36名, すべて摂取した母親は 18名であった。統計学的有意差はなかった（P= $0.43 ） か ゙ ， 1$ 週間単位で 3 種類すべて捸取した母 親から分泌された初乳中 BPA 濃度が $3.56 \mathrm{ng} / \mathrm{ml}$, $1 \sim 2$ 種類摂取していた母親は $3.28 \mathrm{ng} / \mathrm{ml}$, まっ

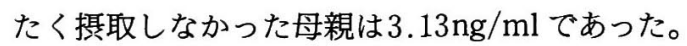
統計学的有意差は認めなかったが, すべて摂取し ていた，1〜2種類摂取していた，まったく摄取 しなかった群の順で高い傾向を認めた。

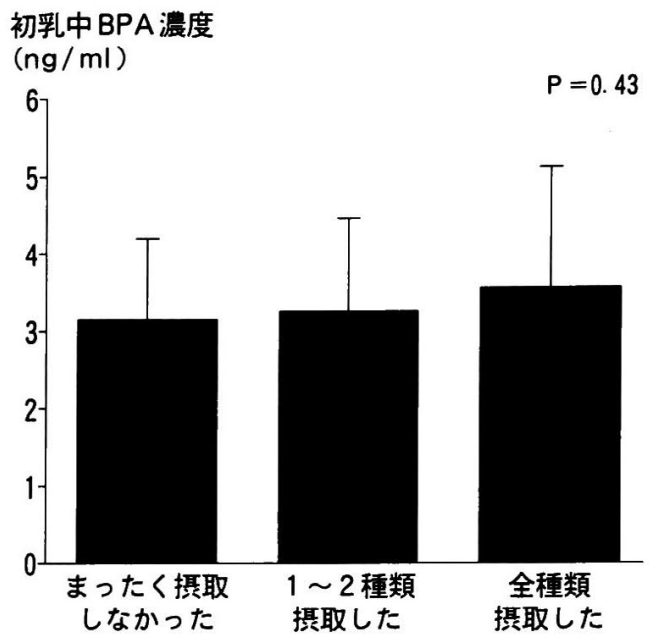

図 5

食器包装容器複数使用之初乳中BPA 濃度 (カップめん・缶コーヒー飲料・ペットボトル)

\section{V 考察}

\section{1. 初乳中 BPA 濃度}

これまでに，母乳中 BPA 濃度に関する研究報告 は皆無である。母乳試料以外で報告されている七 トサンプルの BPA 濃度結果を表 3 に示す。臍帯血 や羊水, 成人血清中の BPA 濃度の測定結果と比較 すると，高濃度であることが明らかとなった。今 回，102検体（100\%）すべての初乳検体から BPA が抽出されたこと，またその濃度が，血清や臍帯 血・羊水に比べて高い濃度であることは，授乳行 為により，初乳を摂取する新生児に BPA が移行し ていることを示唆している。母乳中のダイオキシ ン類については, 哺乳期間が長くなると濃度は次 第に減少し，第 1 子に比べ第 2 子以後の児が哺乳

表 3 これまでに報告されているヒトサンプルの BPA 濃度結果

\begin{tabular}{l|c|c|c}
\hline \multicolumn{1}{c|}{ 測定検体 } & 平原 & Takeuchi et al. & Kuroda et al. \\
\hline 母体血清 & $0.4 \pm 0.29$ & $1.49 \pm 0.11$ & $0.46 \pm 0.20$ \\
成人男性血清 & & $0.64 \pm 0.10$ & \\
成人女性血清 & & & $0.62 \pm 0.13$ \\
臍帯血 & $1.37 \pm 2.29$ & & $0.56 \pm 0.19$ \\
羊 水 & & & \\
尿道下裂患者の母親血清 & $1.32 \pm 0.93$ & & \\
\hline
\end{tabular}


表 4 食器包装容器

\begin{tabular}{|c|c|c|c|}
\hline & $\begin{array}{c}\text { 環境ホルモンに関する } \\
\text { これまでの研究結果 } \\
\end{array}$ & 報告者 & 国内の動き \\
\hline 1. ラップ & $\begin{array}{l}\text { •塩化ビニル製食品用ラップか } \\
\text { らは, 0.9 23.5 ppb } \\
\text { BPAが検出された。 }\end{array}$ & $\begin{array}{l}\text { ·平成10年かながわの環 } \\
\text { 境 (環境ホルモン情報 } \\
\text { 集) 検查機関: 茅ヶ崎 } \\
\text { 及び厚木保健福祉事務 } \\
\text { 所 }\end{array}$ & $\begin{array}{l}\text { ・環境ホルモン全国市民団体 } \\
\text { テーブルは, 全国で集めた } \\
\text { 塩化ビニリテン製ラップ約 } \\
21,500 \text { 本をメーカー2 社に } \\
\text { 返品した (99.11.18) } \\
\text { ·家庭用塩化ビニル製ラップ } \\
\text { を全廃し, ポリエチレンな } \\
\text { どの非塩ビ系に切り替える } \\
\text { 企業を掲載した ( } \\
\text { 18, 毎日新聞) }\end{array}$ \\
\hline $\begin{array}{l}\text { 2. ポリカーボネイト } \\
\text { 製耐熱容器 }\end{array}$ & 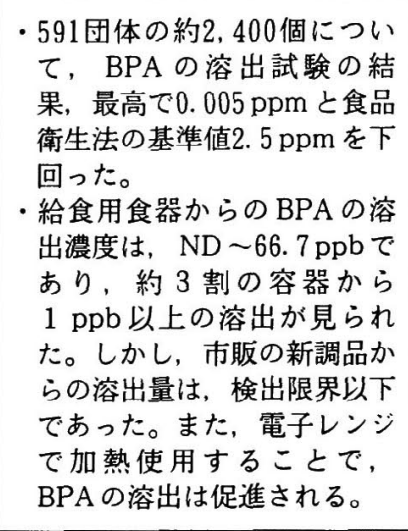 & 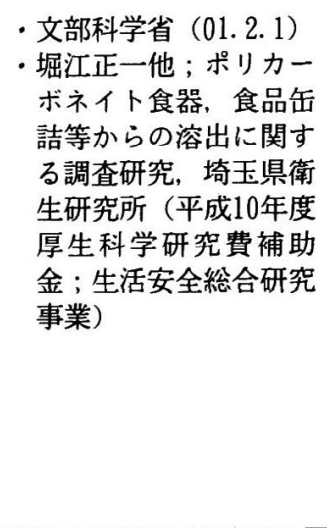 & $\begin{array}{l}\text { 平成 } 10 \text { 年文部省が給食食器か } \\
\text { らの BPAの溶出について㦟 } \\
\text { 念を示し, 他の材質への切り } \\
\text { 替えを指導した。 }\end{array}$ \\
\hline 3. ペットボトル飲料 & 研究報告なし & & $\begin{array}{l}\text { かなり普及されており, プラ } \\
\text { スティック容器であることも } \\
\text { あり, 研究成果が待たれてい } \\
\text { る。 }\end{array}$ \\
\hline 4. コンビニ弁当 & $\begin{array}{l}\text { コンビニ弁当からは, } 6 \text { 検体中 } \\
3 \text { 検体から } 2 \mathrm{ng} / \mathrm{g} \text { の BPAが検 } \\
\text { 出された。レトルトハック食品 } \\
\text { からは, } 11-86 \mathrm{ng} / \mathrm{g} \text { のPAが } \\
\text { 検出された。 }\end{array}$ & $\begin{array}{l}\text { 今中雅章; フェノール類 } \\
\text { の食品污染実態及び摄取 } \\
\text { 量に関する調査研究一各 } \\
\text { 種食品の BPA 污染実態 } \\
\text { 調査-(厚生科学研究費 } \\
\text { 補助金) }\end{array}$ & $\begin{array}{l}\text { 厚生省が, 調理用塩化ビニル } \\
\text { 手袋の使用禁止を決める。 } \\
(00.5)\end{array}$ \\
\hline 5. カップめん & $\begin{array}{l}\text { 発泡スチレン性容器からは, } \\
\text { BPA が溶出すると指摘する市 } \\
\text { 民団体に対し, 業界側は環境ホ } \\
\text { ルモン作用はないと主張してい } \\
\text { る。 }\end{array}$ & & $\begin{array}{l}\text { 容器を紙やポリプロピレン製 } \\
\text { に転換しているメーカーがあ } \\
\text { る。 }\end{array}$ \\
\hline 6. 缶入り飲料 & $\begin{array}{l}\text { •缶コーヒー13種のうち, } 11 \text { 種 } \\
\text { からこく微量のBPA（国の } \\
\text { 基準値以下) が検出された。 } \\
\text { ·54銘柄の分析から, } 13 \text { 銘柄に } \\
1.2 \sim 6.0 \mathrm{ng} / \mathrm{g} \text { のPAが検出 } \\
\text { された。コーヒーで } 5.0 \mathrm{ng} / \mathrm{g} \\
\text { さ高かった。 }\end{array}$ & $\begin{array}{l}\text { - 国立医薬品食品衛生研 } \\
\text { 究所 (99.5.15) } \\
\text { - 東京都立衛生研究所宮 } \\
\text { 川弘之他 ; HPLC- } \\
\text { ECDによる缶入り飲 } \\
\text { 料水のビスフェノール } \\
\text { Aの分析より }\end{array}$ & $\begin{array}{l}\text { 国内市場の約 } 9 \text { 割のシェアを } \\
\text { もつ製缶業大手 } 3 \text { 社は, 金属 } \\
\text { 缶の内面叙装をエポキシ采塗 } \\
\text { 料から, 有機溶剤を使用せず, } \\
\text { BPAの溶出を大幅に減らす塗 } \\
\text { 料の実用化を行い, ペット樹 } \\
\text { 脂フィルムの貼り付けにして } \\
\text { いく。(98.5.23, 日本経済新 } \\
\text { 聞 ; } 98.6 .3 \text {, 読売新聞) }\end{array}$ \\
\hline
\end{tabular}


する母乳中ダイオキシン類の濃度は低下すること が報告されている（厚生科学研究報告書, 1999）。

また，正常な男性と女性の血清中 BPA 濃度で は，有意に女性が低濃度であること，またそれが 授乳することによる性差であることが報告されて いる（Takeuchi ら，2000)。しかし，BPA は肝蔵 で代謝され，尿中に排泄されていくことからも（小 平ら，2000），食生活を通して体内に取り込まれて いる。したがって, 分婏歴での初乳中 BPA 濃度で は，経産婦で高い傾向が認められ，BPA が体内に 蓄積されないという体内動態が再確認でき, 食生 活によることが確認された。

BPA の胎児に対する有害性を，さまざまな研究 者が，動物実験によって報告しているが，ヒトに 有害性を及ほしたデー夕は皆無であり, 科学的に 証明されていない。臍帯血が母親の血清中 BPA に 比べて有意に高濃度であることから，体内での蓄 積に関するメカニズムを考察しているが（遠藤, 2000)，明らかな証拠がないのが現状である。しか し，BPA は，これまで毒性学で扱っていた量より もはるかに微量で, 生殖器系・甲状腺・アトピー 性皮膚炎等への影響がでる可能性があることが示 唆されている（Vom Saal, 1998; Cagen, 1999) ことから，まず，BPA を体内に取り込まないよう に，その摂取経路を絶つことが求められる。

\section{2. 初乳中 BPA 濃度と食器包装容器使用との関連}

1998年環境庁（現・環境省）は, 環境ホルモン 戦略計画 SPEED'98 で,「動物の体内に取り込ま れた場合, 本来その生体内で営まれる正常なホル モン作用に影響を与える外因性物質」として，67 物質を選定した。このうちの暴露量と低用量の観 点から研究課題として重要な物質の 1 つに, BPA を挙げた。その理由として，BPA はヒト乳ガン細 胞株の増殖を刺激すること, エストロゲン受容体 に作用することで注目を集めているからである。 私たちは，便利な生活物質に囲まれており，その 代用として，微量ではあるが，日常的に BPA を捸 取しているのが現状である。本研究結果より, 表 2 に挙げた BPA が溶出する食器包装容器をより多 く摂取した母親から分泌された初乳に，有意に BPA が多く含まる傾向が示された。各食器包装容 器の製造元は, BPA 溶出への懸念を示し安全な物
質への変更を進めている（表 4 ）。したがって，母 親が，BPA を体内に摂取する経路を断つような食 生活を心がけることが, 新生児への BPA の移行を 最小限にする手段であると思われる。

\section{3. 初乳中 BPA 含有と母乳栄養に関する今後の 課題}

本研究により, 初めて食生活による BPA の体内 摄取による初乳中への分泌の実態が明らかとなっ た。ダイオキシン類と母乳に関する対策の見解で は, 妊婦やその予備軍の女性に対して, 食事の捸 り方, 個々の魚介類のダイオキシン污染度の十分 な啓蒙活動の必要性が示されているが，BPAに関 しては，何の指針も出されていない。初乳中に BPA が溶出しているという事実を踏まえ, 食生活 における食器包装容器の使用について, 啓蒙の必 要性があると考える。授乳指導を行う助産師の保 健指導内容に, この事実を周知させ，食生活に対 する指導の一項目に加えられることが必要である。

今後の研究課題として, 母乳栄養を行った乳幼 児の BPA の影響を, 生後 1 年間の成長・発達に ついて追跡調査していくことで明らかにし，環境 ホルモンと母乳哺育に関する知見を助産師の立場 から示してゆくことが必要である。

今回の調査において, BPAについての知識を有 していた母親の一人は，「助産師さんが，『母親学級 で食事を作り置きしておいたりして, 時間にゆと りを持ちましょう』と言っていましたが，心配で す」という発言をしていた。更なる研究で, BPA の代謝時間を科学的に明らかにし, 摂取してしまっ た場合の半減期について等の考察を加えた授乳指 導が行えるような検討を進めてゆきたい。

\section{謝辞}

本研究にご協力いただきましたお母様方，フィール ドを提供してくださいました静岡県立総合病院 3D 病 棟のスタッフの皆様に媣く感謝いたします。

なお，本研究は 2001 年度財団法人昭和シェル石油環 境研究助成を受けて行った。また, 本研究の一部は, 第 6 回環境ホルモン学会（仙台）で発表した。

\section{文献}

CagenS. Z. (1999), Normal reproductive organ devel- 
opment in CF-1 mice following prenatal exposure to bisphenol A. Toxicol. sci. 50, 36-44.

遠藤千春（2000）, ダイオキシン・「環境ホルモン」の何が 問題か?，第15回全国環境・公害研究所交流シンポジ ウム予稿集, 75-78.

平原史樹 (2002), 日本における妊娠女性, 胎児の内分泌 擋乱化学物質の暴露状況, 第 5 回内分泌擋乱化学物質 問題に関する国際シンポジウム報告書.

小平司, 小栗英生, 矢内原昇 $(2000)$, 内分泌擋乱物質, bisphenol-A の簡易 ELISA の確立とその評価, 消化 管ホルモン (別冊), 74-76.

厚生科学研究 (1999), 母乳中のダイオキシン類に関する研 究 (主任研究者多田裕), 平成10年度研究報告書.

久留戸涼子, 立岡弓子, 臼杵靖晃 (2003), Measurement of bisphenol A levels in human colostrum, 第 6 回日本内分泌擋乱化学物質学会要旨集, 100 .

Naotaka Kuroda \& Yumi Kinoshita (2003), Measure- ment of bisphenol A levels in human blood serum and ascetic fluid by HPLC using a fluorescent labeling reagent, J. Pharm and Biomed Anal. 30, 1743-1749.

立岡弓子 (2003), 初乳中 BPA とリスク評価, 第 7 回昭和 シェル石油環境助成研究成果報告書, 23-24。

Toru Takeuchi \& Osamu Tsutsumi (2002), Serum Bisphenol A Concentrations Showed Gender Differences, Possibly Linked to Androgen Levels, Biochem Biophys Res Commun, 291, 76-78.

Vom Saal. (1998), A physiologically based approach to the study of bisphenol $A$ and other estrogenic chemicals on the size of reproductive organs, daily sperm prodiction, and behavior, Toxicol. Ind. Health 14, 239-260.

William, B. P. (1989), Breast milk Immunity, Am J Dis Child, 113, 83-87. 